\title{
Measurements of hydrocarbon emissions from a boreal fen using the REA technique
}

\author{
S. Haapanala ${ }^{1}$, J. Rinne ${ }^{1}$, K.-H. Pystynen ${ }^{2}$, H. Hellén ${ }^{2}$, H. Hakola ${ }^{2}$, and T. Riutta ${ }^{3}$ \\ ${ }^{1}$ University of Helsinki, Department of Physical Sciences, Helsinki, Finland \\ ${ }^{2}$ Finnish Meteorological Institute, Air Chemistry Laboratory, Helsinki, Finland \\ ${ }^{3}$ University of Helsinki, Department of Forest Ecology, Helsinki, Finland
}

Received: 30 August 2005 - Published in Biogeosciences Discuss.: 14 October 2005

Revised: 18 January 2006 - Accepted: 3 February 2006 - Published: 14 March 2006

\begin{abstract}
Fluxes of biogenic volatile organic compounds (VOC) and methane were measured above a boreal fen. Vegetation on the fen is dominated by Sphagnum mosses and sedges. A relaxed eddy accumulation (REA) system with dynamic deadband was designed and constructed for the measurements. Methane, $\mathrm{C}_{2}-\mathrm{C}_{6}$ hydrocarbons and some halogenated hydrocarbons were analysed from the samples by gas chromatographs equipped with FID and ECD. A significant flux of isoprene and methane was detected during the growing seasons. Isoprene emission was found to follow the common isoprene emission algorithm. Average standard emission potential of isoprene was $680 \mu \mathrm{g} \mathrm{m}^{-2} \mathrm{~h}^{-1}$. Fluxes of other non-methane hydrocarbons were below detection limit.
\end{abstract}

\section{Introduction}

Wetlands cover an area of about $2.5 \times 10^{6} \mathrm{~km}^{2}$, which equals to almost $2 \%$ of the total land surface area of the world. Most of the wetlands are located in the boreal and tundra zones on the northern hemisphere (Archibold, 1995). In Finland, the wetlands have covered over one third of the land area but a large portion of the wetlands have been drained for agriculture and forestry during the 20th century. Today there is nearly $50000 \mathrm{~km}^{2}$ of wetland in Finland, which accounts for about one sixth of the total land surface area (Vasander, 1996). Wetland ecosystems are known as a major source of atmospheric methane (e.g. Enhalt et al., 2001) but they have also been reported to emit volatile organic compounds (Klinger et al., 1994; Janson and De Serves, 1998; Janson et al., 1999; Varner et al., 1999; Dimmer et al., 2001; Rinnan et al., 2005).

Correspondence to: S. Haapanala

(sami.haapanala@helsinki.fi)
Volatile organic compounds (VOC) are a diverse group of substances that have many impacts on the atmospheric chemistry. They react with ozone, nitrate and hydroxyl radicals and produce oxygenated compounds such as aldehydes, ketones and organic acids. High VOC concentration together with $\mathrm{NO}_{\mathrm{x}}$ can increase ozone levels in the lower troposphere (e.g. Chameides et al., 1992) and form organic aerosols (e.g. Kulmala et al., 2000).

Significant atmospheric concentrations of biogenic VOCs, such as monoterpenes, isoprene and other light hydrocarbons, have been measured in the boreal areas. Scaling the VOC concentrations by the reactivity with ozone and $\mathrm{OH}-$ radical shows that biogenic compounds dominate over anthropogenic ones in rural and remote areas (Laurila and Hakola, 1996; Hakola et al., 2000). It is known that monoterpenes $\left(\mathrm{C}_{10} \mathrm{H}_{16}\right)$ participate in aerosol formation (Hoffmann et al., 1997) and, recently, evidence of isoprene $\left(\mathrm{C}_{5} \mathrm{H}_{8}\right)$ taking part in the aerosol formation and growth has been discovered (Claeys et al., 2004).

Globally the emissions of VOCs are estimated to be dominated by biogenic sources (Guenther et al., 1995). Also in the boreal regions of Northern Europe the biogenic VOC emission is estimated to exceed the anthropogenic sources (Simpson et al., 1999; Lindfors et al., 2000). However, these estimates are uncertain as some ecosystems have been overlooked.

Most of the work aimed at quantifying the VOC emissions from boreal ecosystems has been conducted in forest ecosystems. Isidorov et al. (1985) conducted early measurements of several VOCs from 22 different plant species typical in forests of northern hemisphere. Later, the VOC emissions from boreal plant species have been measured by e.g. Janson (1993), Hakola et al. (1998, 2001), Janson et al. (1999) and Janson and De Serves (2001) using enclosure techniques. The dominant coniferous tree species in the European boreal zone are observed to emit mainly monoterpenes and carbonyls (Janson, 1993; Janson and De Serves,

Published by Copernicus GmbH on behalf of the European Geosciences Union. 
Table 1. Proportion (\% of area) of different microforms in the study site and the projection coverage (\%) of three dominant vascular and moss species in each microform.

\begin{tabular}{|c|c|c|c|c|c|}
\hline \multirow[t]{2}{*}{ Microform } & $\begin{array}{c}\text { Proportion } \\
\text { [\%] }\end{array}$ & \multicolumn{2}{|c|}{$\begin{array}{l}\text { Dominant vascular species } \\
\qquad[\%]\end{array}$} & \multicolumn{2}{|c|}{$\begin{array}{l}\text { Dominant moss species } \\
{[\text { [\%] }}\end{array}$} \\
\hline & \multirow{3}{*}{74} & Eriophorum vaginatum & 3 & Sphagnum balticum & 39 \\
\hline \multirow{2}{*}{ Lawn } & & Andromeda polifolia & 2 & Sphagnum papillosum & 35 \\
\hline & & Betula nana & 2 & Sphagnum magellanicum & 9 \\
\hline \multirow{3}{*}{ Hummock } & \multirow{3}{*}{19} & Rubus chamaemorus & 5 & Sphagnum magellanicum & 30 \\
\hline & & Andromeda polifolia & 5 & Sphagnum papillosum & 16 \\
\hline & & Betula nana & 3 & Sphagnum angustifolium & 15 \\
\hline \multirow{3}{*}{ Hollow } & \multirow{3}{*}{7} & Carex limosa & 0.8 & Sphagnum majus & 61 \\
\hline & & Carex rostrata & 0.6 & Sphagnum balticum & 13 \\
\hline & & Andromeda polifolia & 0.4 & Sphagnum papillosum & 12 \\
\hline
\end{tabular}

2001). However, Norway spruce (Picea abies) has been measured to emit also isoprene (Janson and De Serves, 2001) and some of the boreal broadleaved tree species, such as European aspen (Populus tremula) and tea-leafed willow (Salix phylicifolia) are found to be high isoprene emitters (Hakola et al., 1998).

In addition to the enclosure techniques, VOC emission of boreal forest ecosystems have been measured by micrometeorological flux measurement techniques. Pattey et al. (1999) measured an average isoprene flux of $2600 \mu \mathrm{g} \mathrm{m}^{-2} \mathrm{~h}^{-1}$ in late July and $610 \mu \mathrm{g} \mathrm{m}^{-2} \mathrm{~h}^{-1}$ in early September above a black spruce forest. Rinne et al. (1999, 2000a, 2000b) and Spanke et al. (2001) measured monoterpene fluxes up to $400 \mu \mathrm{g} \mathrm{m}^{-2} \mathrm{~h}^{-1}$ and negligible isoprene fluxes above various boreal forests dominated by Scots pine.

VOC emissions from wetland ecosystems have been studied less than those from forest ecosystems. However, according to Klinger et al. (1994), Janson and De Serves (1998) and Janson et al. (1999) the boreal wetlands emit high amounts of isoprene. Varner et al. (1999) and Dimmer et al. (2001) reported also emissions of halogenated hydrocarbons, such as methyl chloride, methyl bromide and chloroform, from midlatitude wetlands. Rinnan et al. (2005) identified emissions of various VOC substances from peatland microcosms. All these measurements were performed with chamber technique.

We performed ecosystem level flux measurements of several VOCs, including some halogenated hydrocarbons, using the relaxed eddy accumulation (REA) technique. Our aims were to study different compounds produced by boreal fens, quantify the ecosystem level emission rates and calculate corresponding standard emission potentials for emission inventories. The measurements were performed over whole growing season to study the effects of different weather conditions and seasonal development.

\section{Materials and methods}

The measurements were carried out at Siikaneva, which is an open minerotrophic fen, located in Southern Finland $\left(61^{\circ} 48^{\prime} \mathrm{N}, 24^{\circ} 09^{\prime} \mathrm{E}, 160 \mathrm{~m}\right.$ a.s.l.), in the southern boreal zone. Siikaneva is about five kilometres west from Hyytiälä Forestry Field Station and SMEAR II measurement station (Vesala et al., 1998). The annual mean temperature in the area is $3^{\circ} \mathrm{C}$. The warmest month is July with mean temperature of $16^{\circ} \mathrm{C}$ and the coldest is February with mean temperature of $-8^{\circ} \mathrm{C}$. The annual mean precipitation is $700 \mathrm{~mm}$ (Drebs et al., 2002). About one third of the precipitation falls down as snow.

Systematic vegetation inventory at the measurement site was carried out in 2005. Altogether 139 sample plots were laid out in the circular inventory area having a radius of $200 \mathrm{~m}$. Vegetation in the site is homogeneous and surface is uniform, mostly lawn level (74\%) with occasional low hummocks (19\%) and hollows (7\%). Ground layer of the vegetation is a continuous moss carpet, Sphagnum mosses covering 93\% of the surface. Dominant species are S. balticum and S. papillosum in lawns, S. magellanicum in hummocks and S. majus in hollows. Field layer is relatively scarce. The coverage of vascular plants is on average $13 \%$, which is roughly equal to $0.4 \mathrm{~m}^{2} \mathrm{~m}^{-2}$ of one-sided leaf area at the peak season. Dominant species are evergreen shrub Andromeda polifolia and aerenchymatous sedges Eriophorum vaginatum and Carex rostrata. Properties of different microforms are shown in Table 1. Similar vegetation consisting of Sphagnum carpet, sedges and dwarf shrubs is typical for Finnish, Swedish and Russian aapa fens (Gore, 1983). The fen is surrounded by coniferous forests. Homogenous fetch extends from the measurement site up to about $200 \mathrm{~m}$ in south and north and to several hundreds of metres in east and west.

Flux measurements were performed with the relaxed eddy accumulation (REA) technique. The principle of REA 


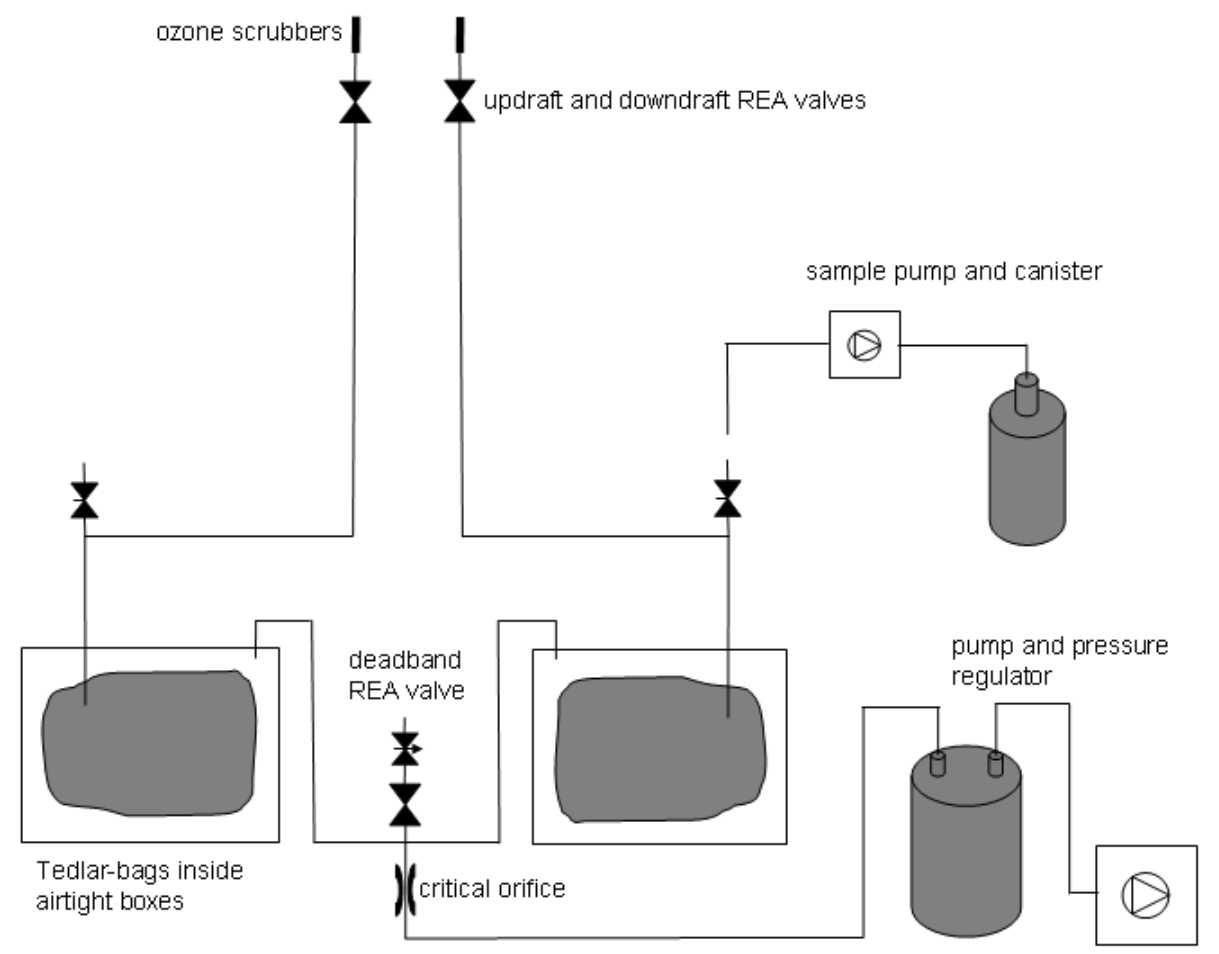

Fig. 1. A block diagram of the REA flow system used in this study.

method was originally proposed by Businger and Oncley (1990) and ever since it has been widely applied for flux measurements of trace gases and aerosol particles (e.g. Guenther et al., 1996; Pattey et al., 1999; Christensen et al., 2000; Gaman et al., 2004; Lee et al., 2005; Olofsson et al., 2005). In the REA system air samples are accumulated in two separate reservoirs during updrafts and downdrafts. Vertical flux $F$ is given by

$$
F=\beta \sigma_{w}\left(C_{\mathrm{UP}}-C_{\mathrm{DOWN}}\right),
$$

where $\beta$ is an empirical dimensionless coefficient, $\sigma_{w}$ is the standard deviation of the vertical wind velocity $w$ and $C_{\mathrm{UP}}$ and $C_{\text {DOWN }}$ are average concentrations of updraft and downdraft reservoirs, respectively. A deadband (sampling threshold), where air parcels with low vertical velocity are not accumulated, is often used.

We designed and constructed a REA system that is suitable for flux measurements of light hydrocarbons. Sonic anemometer (METEK USA-1), with internal 3-D head correction, measures three dimensional wind speed vector ten times per second. Sonic data is read in real time by a computer which calculates $30 \mathrm{~s}$ running box averages of wind speed components as well as other statistics. After each wind measurement a decision of which valve should be open is made. The REA system employs a dynamic deadband with threshold of $\pm 0.5 \sigma_{w}$, where $\sigma_{w}$ is the running standard deviation. This increases the concentration difference between the two reservoirs thus decreasing the precision requirement for the chemical analysis. The dynamic deadband also forces the parameter $\beta$ to become practically constant $(\beta=0.41)$ and independent of turbulence intensity or atmospheric stability (Christensen et al., 2000; Ammann and Meixner, 2002; Grönholm et al., $2006^{1}$ ). Variations in the value of the parameter $\beta$ cause large uncertainty to a single measurement point. However, these variations tend to cancel out in large datasets. For further details of the REA control software used in this study, see Gaman et al. (2004).

Schematic of the REA system is shown in Fig. 1. Air samples were taken in through ozone scrubbers that consist of three plies of $\mathrm{MnO}_{2}$-coated net. Three plies was found to be a reasonable compromise between ozone destruction efficiency and undisturbed sampling (e.g. Calogirou et al., 1996; Hakola et al., 2003). Air is drawn through PFA tubing with $3 \mathrm{~mm}$ inner diameter to valves with ETFE body (Bürkert 117). Air samples are accumulated in Tedlar-bags (SKC 231, 101). Tedlar-bags are used as the primary sampling reservoirs because that way it is possible to maintain constant sampling flow throughout the measurement period. Pressure inside the bags is almost equal to the ambient pressure all the time. The sample bags are located inside airtight boxes. Bags are filled by pressure difference between the box and ambient air, thus avoiding potentially contaminat-

1 Grönholm, T., Rinne, J., Haapanala, S., Rannik, Ü., and Vesala, T.: The dependence of the $\beta$ coefficient of REA system with dynamic deadband on atmospheric conditions, Environ. Pollut., submitted, 2006. 
(a)

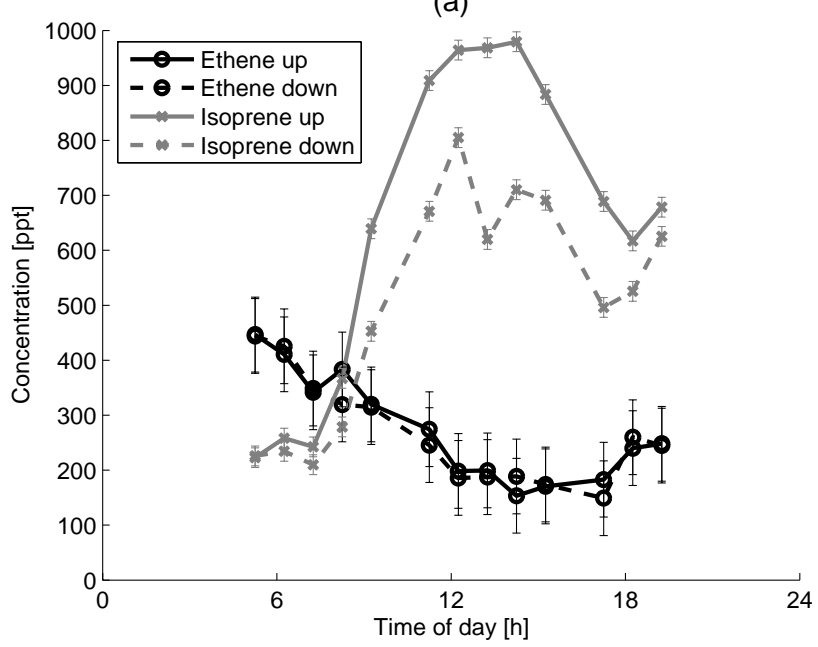

(b)

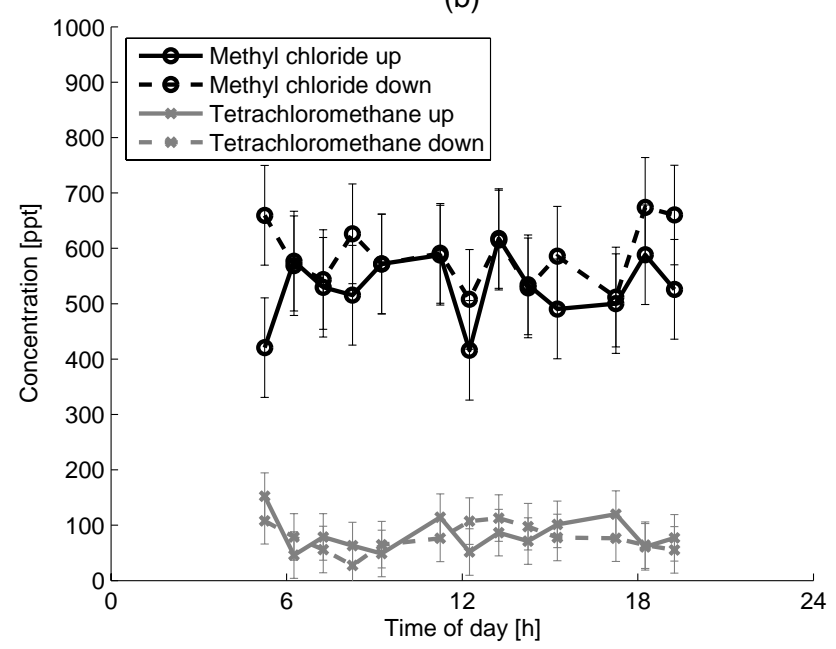

Fig. 2. An example of updraft and downdraft concentrations on 4 August 2004 of selected (a) light hydrocarbons and (b) halogenated hydrocarbons together with their uncertainties.

ing pumps in the sampling system. Pressure difference is achieved by pumping air out from the boxes through a critical orifice $\left(Q=11 \mathrm{~min}^{-1}\right)$. Each line/bag was used as updraftand downdraft reservoirs by turns. This was to avoid biasing the average results if there happens to be some small differences between the lines/bags. The flux measurement height was $3 \mathrm{~m}$.

After the half hour sampling period the air samples were pumped with a Teflon coated pump from the bags into previously evacuated stainless steel canisters (BRC Rasmussen, 0.851 ) for non-methane hydrocarbon analysis and plastic syringes $(50 \mathrm{ml})$ for methane analysis.

Chemical analysis of the canister samples was done at the Finnish Meteorological Institute for 24 different $\mathrm{C}_{2}-\mathrm{C}_{6}$ substances and seven halogenated hydrocarbons. The samples were analyzed within one week of the sampling. Previous work has shown that these compounds preserve in the stainless steel canisters for at least one week (e.g. Zielinska et al., 1996, and references therein). Analysis was carried out using a gas chromatograph (HP-6890) with an $\mathrm{Al}_{2} \mathrm{O}_{3} / \mathrm{KCl}$ PLOT column $(50 \mathrm{~m} \times 0.32 \mathrm{~mm}$ i.d.). Light hydrocarbons and halogenated hydrocarbons were analyzed simultaneously from the same sample. The analytical column was split into two detectors. Flame ionization detector (FID) was used for light hydrocarbons and electron capture detector (ECD) for halogenated hydrocarbons. The samples were pre-concentrated in cold trap using liquid nitrogen before analysis. The light hydrocarbons were calibrated using the VOC mixture standard from the NPL laboratory (UK) and halogenated hydrocarbons were calibrated using standard from NOAA (US). A detailed description of the analysis is given by Hakola et al. (2000).
Methane analysis from the syringes was done at the Hyytiälä Forestry Field station within one day of the sampling. An HP-5890A gas chromatograph equipped with $6 \mathrm{ft} \times 1 / 8^{\prime \prime}$ column and a FID was used. Due to coincidental interferences, four separate analyses were taken from each syringe. Clear outliers were removed from the data and the median concentration was used for flux calculation. Average of the standard deviations was about $0.01 \mathrm{ppm}$ with mean concentration being $1.95 \mathrm{ppm}$.

Supporting meteorological measurements at Siikaneva includes air temperature at $1.5 \mathrm{~m}$ height, air humidity, intensity of photosynthetic photon flux density (PPFD), soil temperatures at depths of $5 \mathrm{~cm}$ and $20 \mathrm{~cm}$ and water table height. These are stored as ten minutes averages.

To ensure that the assumptions of the micrometeorological method were fulfilled, periods when the average friction velocity had been below $0.1 \mathrm{~m} \mathrm{~s}^{-1}$ were discarded from the data analysis.

The measurements were performed during summers of 2004 and 2005, altogether on 14 separate days. The first period was between 8 July 2004 and 6 October 2004 and the second was between 14 April 2005 and 1 July 2005.

\section{Results and discussion}

In Fig. 2 an example of updraft and downdraft concentrations of selected hydrocarbons together with their uncertainties are shown. Uncertainties were obtained by analyzing a set of VOC samples twice and calculating the analytical uncertainty as the mean deviation of these parallel analysis results. The sample set used for the estimation of uncertainties was taken regularly at two background stations having similar 

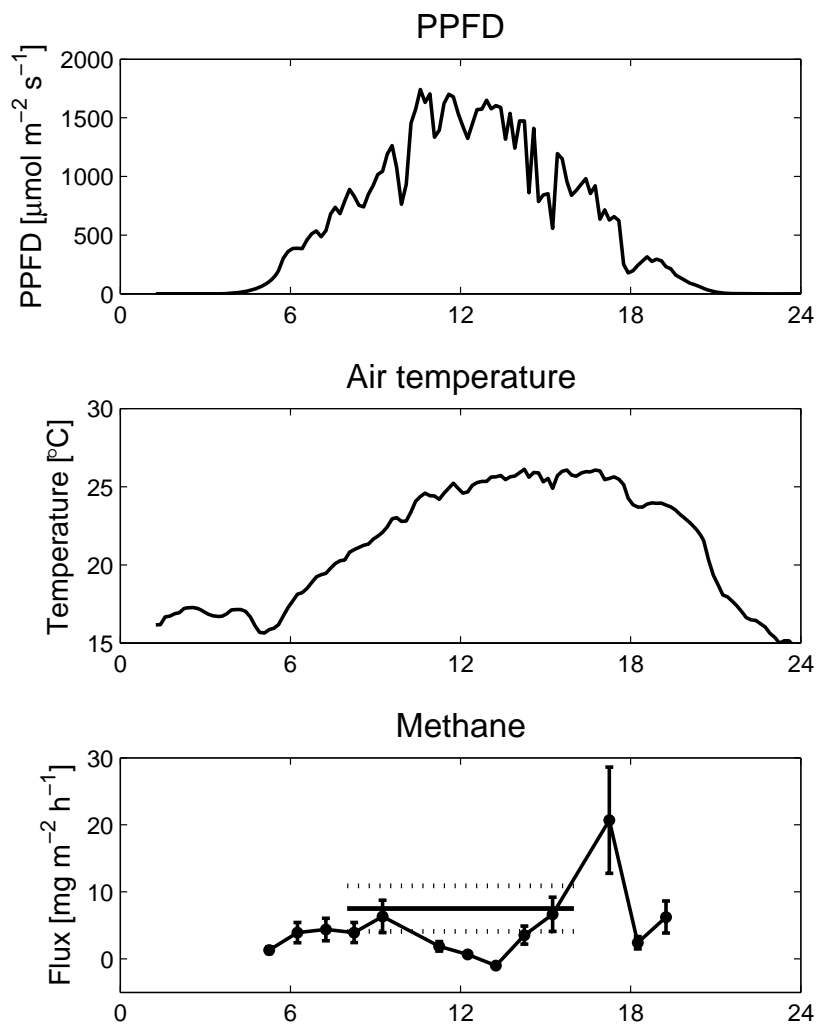

Isoprene

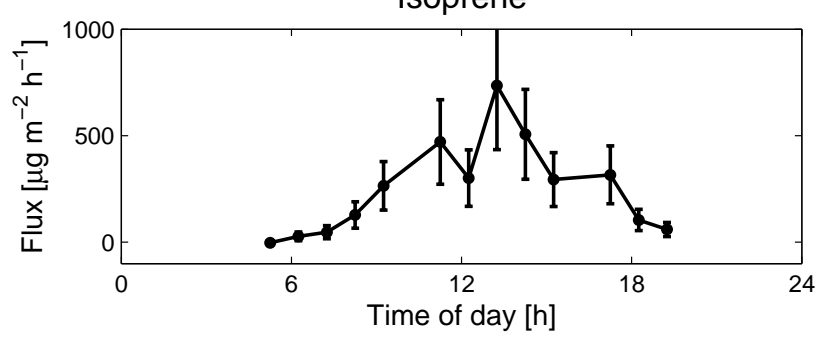

Fig. 3. Measurements on 4 August 2004. Upper panels show PPFD (photosynthetic photon flux density) and air temperature. Lower panels show measured fluxes of methane and isoprene and their error estimates. Solid horizontal line in the methane flux plot shows average methane flux measured by chambers at the same time. Dotted lines indicate \pm std of the chamber dataset.

concentrations as at Siikaneva (Laurila and Hakola, 1996). In Table 2 the concentration detection limits, mean concentrations of hydrocarbons at Siikaneva, precisions of the canister sampling and analysis system and corresponding flux detection limits are shown. The flux detection limits are derived using the Eq. (1) by substituting the concentration difference with the uncertainty of the analysis and by using typical value of $\sigma_{w}\left(\sigma_{w}=0.4 \mathrm{~m} \mathrm{~s}^{-1}\right)$. On 14 April 2005 the isoprene concentrations of both updrafts and downdrafts were nearly zero indicating negligible emission and thus these measurements were excluded from the further analysis.
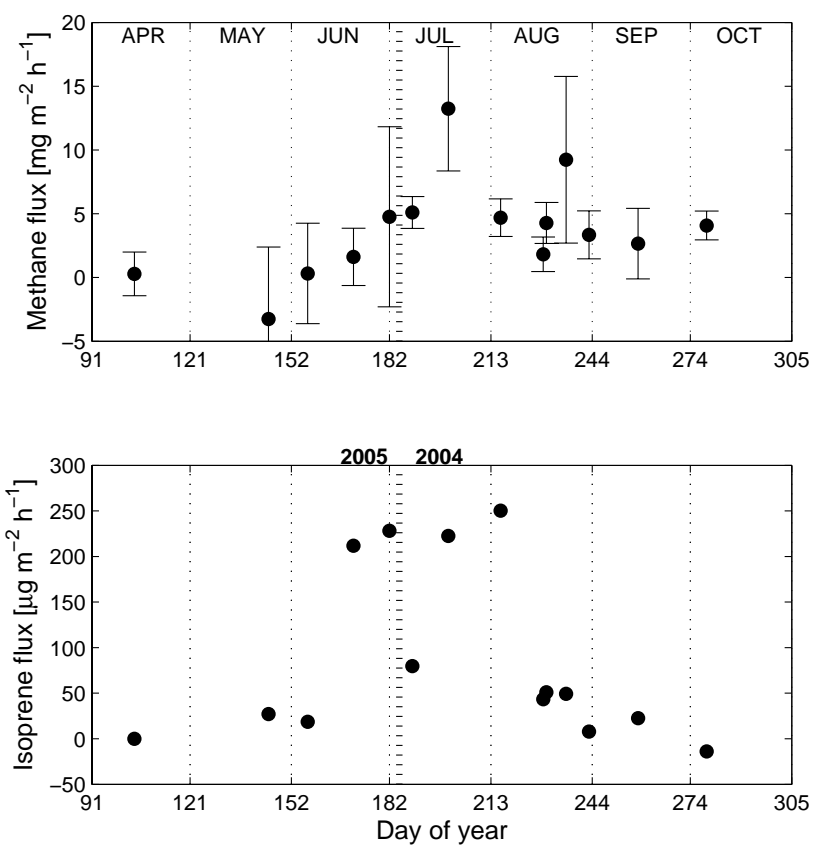

Fig. 4. Daily average methane and isoprene fluxes for the whole measurement period. Error bars in the methane flux plot indicate standard errors of the means. Due to strong daily pattern, these are not shown for isoprene.

The highest observed flux of non-methane hydrocarbons was that of isoprene. In Fig. 3 examples of measured methane and isoprene fluxes together with light and temperature data during one day are shown. Figure 4 shows daily averages of methane and isoprene fluxes during the whole measurement period. Methane fluxes typically varied between 0 and $10 \mathrm{mg} \mathrm{m}^{-2} \mathrm{~h}^{-1}$. Large temporal variations occurred in the flux. Mean methane emission during the whole measurement period was $4.3 \mathrm{mg} \mathrm{m}^{-2} \mathrm{~h}^{-1}$. These methane fluxes were compared to the fluxes measured at Siikaneva by enclosure method and eddy covariance method. Enclosure measurements were conducted on 18 vegetated sample plots with $56 \times 56 \mathrm{~cm}$ permanent aluminium collars which had collars with a water groove that enabled the air-tight sealing of the measurement system. For the measurements, an aluminium chamber of $0.11 \mathrm{~m}^{3}$, equipped with a fan, was put on top of the collar. Air samples were drawn to plastic syringes $(40 \mathrm{ml})$ at 5, 15, 25 and 35 min after closing the chamber. Samples were analysed with GC-FID within one day after sampling (as the REA samples). Methane flux was determined by calculating the slope of the least squares regression line between $\mathrm{CH}_{4}$ concentrations and time.

In 2005 ecosystem level methane fluxes were measured continuously with eddy covariance (EC) method at $3 \mathrm{~m}$ height, less than $50 \mathrm{~m}$ from the REA tower. The EC system employs similar Metek anemometer as the REA system and a tunable diode laser trace gas analyzer (TGA100, Campbell 
Table 2. Analyzed non-methane hydrocarbons, their concentration detection limits, mean concentrations at Siikaneva, average standard deviation derived from 233 parallel samples and corresponding flux detection limit.

\begin{tabular}{|c|c|c|c|c|}
\hline Substance & $\begin{array}{l}\text { Concentration } \\
\text { detection limit } \\
\text { [ppt] }\end{array}$ & $\begin{array}{c}\text { Mean concentration } \\
\text { at Siikaneva } \\
{[\mathrm{ppt}]}\end{array}$ & $\begin{array}{c}\text { Standard deviation } \\
\text { of parallel samples } \\
\text { [ppt] }\end{array}$ & $\begin{array}{l}\text { Flux detection } \\
\text { limit } \\
{\left[\mu \mathrm{g} \mathrm{m}^{-2} \mathrm{~h}^{-1}\right]}\end{array}$ \\
\hline ethane & 6 & 949 & 53 & 38 \\
\hline ethene & 8 & 211 & 34 & 22 \\
\hline propane & 7 & 279 & 26 & 27 \\
\hline propene & 10 & 47 & 15 & 15 \\
\hline 2-methylpropane & 8 & 70 & 9 & 13 \\
\hline ethyne & 20 & 205 & 25 & 15 \\
\hline butane & 7 & 97 & 25 & 34 \\
\hline trans-2-butene & 9 & 10 & 5 & 7 \\
\hline 1-butene & 8 & 18 & 8 & 11 \\
\hline 2-methylpropene & 8 & 51 & 17 & 22 \\
\hline cis-2-butene & 7 & 3 & 6 & 8 \\
\hline 2-methylbutane & 7 & 70 & 7 & 12 \\
\hline pentane & 7 & 83 & 6 & 10 \\
\hline propyne & 13 & 8 & 8 & 8 \\
\hline 1,3-butadiene & 9 & 2 & 21 & 26 \\
\hline trans-2-pentene & 11 & 7 & 12 & 20 \\
\hline cis-2-pentene & 10 & 7 & 10 & 17 \\
\hline cyclohexane & 6 & 67 & 2 & 5 \\
\hline 2-methylpentane & 8 & 26 & 3 & 6 \\
\hline 3-methylpentane & 6 & 49 & 2 & 5 \\
\hline hexane & 6 & 146 & 3 & 6 \\
\hline isoprene & 10 & 232 & 9 & 14 \\
\hline heptane & 5 & 38 & 5 & 11 \\
\hline benzene & 4 & 67 & 11 & 21 \\
\hline CFC-12 & 2 & 538 & 14 & 41 \\
\hline methyl chloride & 5 & 520 & 45 & 53 \\
\hline trichlorofluoromethane & 1 & 259 & 7 & 23 \\
\hline dichloromethane & 1 & 28 & 8 & 16 \\
\hline tetrachloromethane & 104 & 55 & 21 & 77 \\
\hline tetrachloroethene & 1 & 5 & 1 & 5 \\
\hline
\end{tabular}

Scientific, USA) for fast online methane analysis. Sample flow is drawn through a Nafion diffusive drier to avoid water vapour interferences. This system is similar to the TDL system used by Laurila et al. (2005).

In Fig. 3 the average methane flux $\left(7.5 \pm 3.4 \mathrm{mg} \mathrm{m}^{-2} \mathrm{~h}^{-1}\right)$ obtained by enclosure measurements on 14 August 2004 is shown. Average methane emission measured by enclosure method during the whole REA measurement period was $4.7 \mathrm{mg} \mathrm{m}^{-2} \mathrm{~h}^{-1}$ (unpublished data). Average value for the growing season 2005 from the eddy covariance data was $3.6 \mathrm{mg} \mathrm{m}^{-2} \mathrm{~h}^{-1}$ (Rinne et al., 2006). Even though the temporal coverage of these measurements differs from that of the REA measurements, they are reasonably close to the mean methane flux, $4.3 \mathrm{mg} \mathrm{m}^{-2} \mathrm{~h}^{-1}$, obtained by the REA system.

Literature values for similar sites (open or sparsely treed fens in boreal areas) indicate mean methane emissions of 3$10 \mathrm{mg} \mathrm{m}^{-2} \mathrm{~h}^{-1}$ during growing seasons (Suyker et al., 1996;
Saarnio et al., 1997; Strack et al., 2004; Bubier et al., 2005). Water table height and soil temperature are known to affect methane production and emission from wetlands. However, no clear dependence was observed in this study. This might be due to small data set and rather inaccurate methane flux detection.

Isoprene fluxes varied typically between 0 and $400 \mu \mathrm{g} \mathrm{m}^{-2} \mathrm{~h}^{-1}$ while the fluxes of other VOCs were below the detection limit of the measurement system. The isoprene fluxes from the Siikaneva fen are in same range with the emissions measured from a boreal fen by Janson and De Serves (1998) and Janson et al. (1999). The daytime isoprene emission rates from Siikaneva were in the same range than the monoterpene emissions from boreal forests (Rinne et al., 1999, 2000a, 2000b; Spanke et al., 2001).

Isoprene emissions are known to be light and temperature dependent. This dependence can be empirically explained by 
an algorithm presented by Guenther et al. (1993) and Guenther (1997). According to the algorithm, isoprene emission $I$ is given by

$I=I_{S} C_{L} C_{T}$,

where $I_{S}$ is the standard emission potential at standard temperature $(303 \mathrm{~K})$ and standard PPFD $\left(1000 \mu \mathrm{mol} \mathrm{m}^{-2} \mathrm{~s}^{-1}\right)$. Light dependence factor $C_{L}$ is defined by

$C_{L}=\frac{\alpha C_{L 1} L}{\sqrt{1+\alpha^{2} L^{2}}}$

where $\alpha(=0.0027)$ and $C_{L 1}(=1.066)$ are empirically determined coefficients and $L$ is PPFD (in $\mu \mathrm{mol} \mathrm{m}^{-2} \mathrm{~s}^{-1}$ ). Temperature dependence factor $C_{T}$ is defined by

$C_{T}=\frac{\exp \left(\frac{C_{T 1}\left(T-T_{S}\right)}{R T_{S} T}\right)}{C_{T 3}+\exp \left(\frac{C_{T 2}\left(T-T_{M}\right)}{R T_{S} T}\right)}$,

where $C_{T 1} \quad\left(=95 \mathrm{~kJ} \mathrm{~mol}^{-1}\right), \quad C_{T 2} \quad\left(=230 \mathrm{~kJ} \mathrm{~mol}^{-1}\right), \quad C_{T 3}$ $(=0.961)$ and $T_{M}(=314 \mathrm{~K})$ are empirically determined coefficients, $R$ is the universal gas constant $\left(=8.314 \mathrm{~J} \mathrm{~K}^{-1} \mathrm{~mol}^{-1}\right)$, $T_{S}(=303 \mathrm{~K})$ is the standard leaf temperature and $T$ is the actual leaf temperature (in $\mathrm{K}$ ).

We calculated light and temperature dependence factor $\left(C_{L} C_{T}\right)$ for each half-hourly measurement using measured PPFD and air temperature. Air temperature was used instead of leaf temperature as the latter was not available. In Fig. 4 the relation between the measured isoprene flux and $C_{L} C_{T}$ is shown. Linear fit gives the standard emission potential of $680 \mu \mathrm{g} \mathrm{m}^{-2} \mathrm{~h}^{-1}$ with $\mathrm{R}^{2}$ of 0.70 . This agrees well with the results of Janson and De Serves (1998), who reported average standard emission potential of $708 \mu \mathrm{g} \mathrm{m}^{-2} \mathrm{~h}^{-1}$ from flarks of boreal wetlands.

There seems to be some systematic deviation of the measured fluxes from the emission algorithm. In Fig. 4 it can be seen that the fit seems to be different for low $(<0.2)$ and high $(>0.2)$ values of $C_{L} C_{T}$. The same is true for monthly subsets of the data. Fit to data where $C_{L} C_{T}$ is below 0.2 leads to standard emission potential of $330 \mu \mathrm{g} \mathrm{m}^{-2} \mathrm{~h}^{-1}$ and data where $C_{L} C_{T}$ is over 0.2 leads to standard emission potential of $740 \mu \mathrm{g} \mathrm{m}^{-2} \mathrm{~h}^{-1}$. One possible explanation is that the emission algorithm does not take into account the differences in the light penetration into the vegetation canopy at different solar angles. The solar radiation might penetrate deeper into the moss at higher solar angles leading to higher isoprene emission rates than obtained by the algorithm. Similarly the relatively inefficient penetration at low solar angles would lead to lower than predicted isoprene emission. This would lead to similar systematic differences between the observed emissions and the emission algorithm.

To study this issue, we simulated light penetration into the moss carpet with extremely simple model. It treats the moss carpet as homogenous medium where light is attenuated as described by Beer's law. The extinction coefficient was determined from light compensation values (about
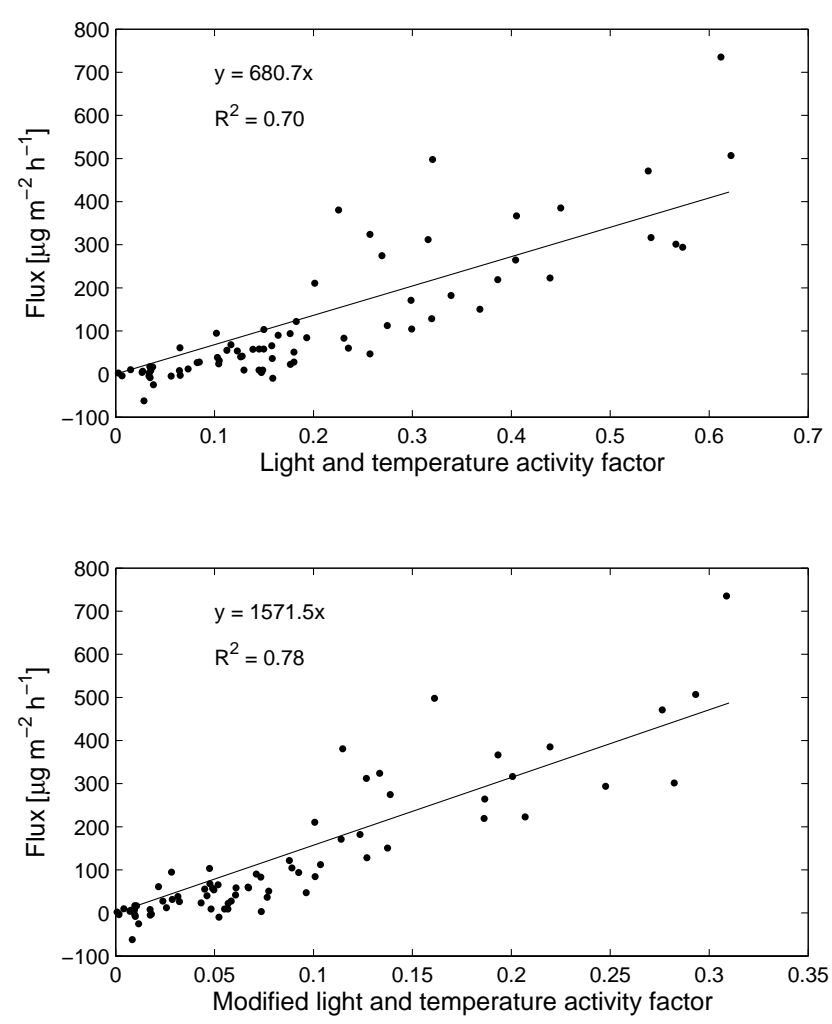

Fig. 5. Measured isoprene flux versus light and temperature activity factor $\left(C_{L} C_{T}\right)$. Linear fit of the dataset determines the standard emission potential. Lower panel show the results of the modified model described in the text.

$30 \mu \mathrm{mol} \mathrm{m}^{-2} \mathrm{~s}^{-1}$ ) for Sphagnum mosses found in the literature (e.g. Riis and Sand-Jensen, 1997) and average depth of green (active biomass) layer in Siikaneva moss carpet $(2.5 \mathrm{~cm})$. Light intensity was calculated in 10 to 22 layers and the Guenther algorithm was applied to each of these. This model was rather insensitive to the modifications of variable values (extinction coefficient, calculation layers). Measured isoprene flux was plotted against $\mathrm{C}_{L} \mathrm{C}_{T}$ averaged over all the model layers. Resulting plot (Fig. 5, lower panel) looks somewhat better $\left(\mathrm{R}^{2}=0.78\right)$ than the original (Fig. 5, upper panel) fit $\left(\mathrm{R}^{2}=0.70\right)$, but the difference is not significant except for the absolute values of $\mathrm{C}_{L} \mathrm{C}_{T}$. Thus we believe that for practical purposes it is better to report values of the original Guenther algorithm, although it was originally developed for leaf-scale use.

Another source of systematic error was the use of ambient air temperature instead of leaf temperature. This might also lead to the underestimation of the flux at high solar elevations when the radiation most effectively warms the surfaces. Leaf temperature of mosses and other wetland vegetation is virtually impossible to measure directly.

Seasonal development seems to have only a weak effect on the isoprene flux during the growing seasons. Emission potentials obtained using the data from September, October or 
(a)
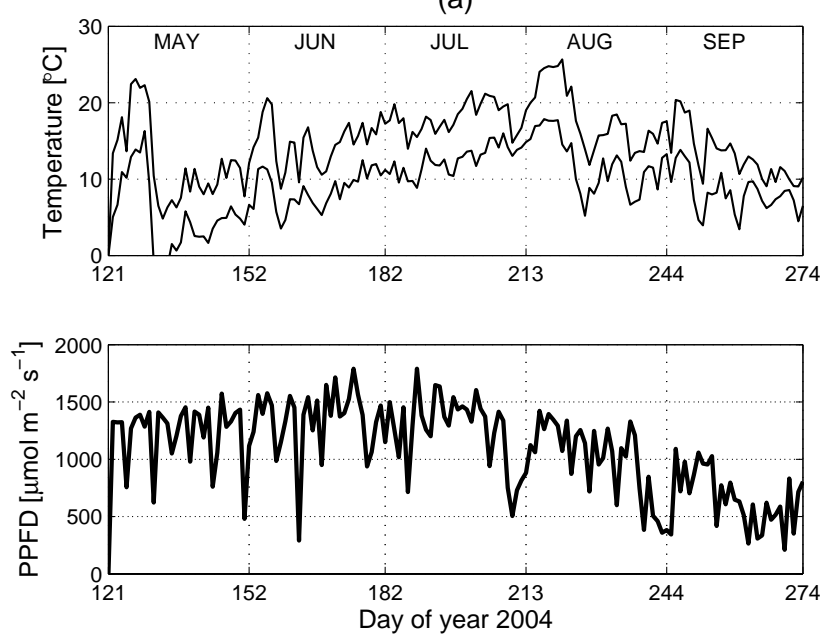

(b)

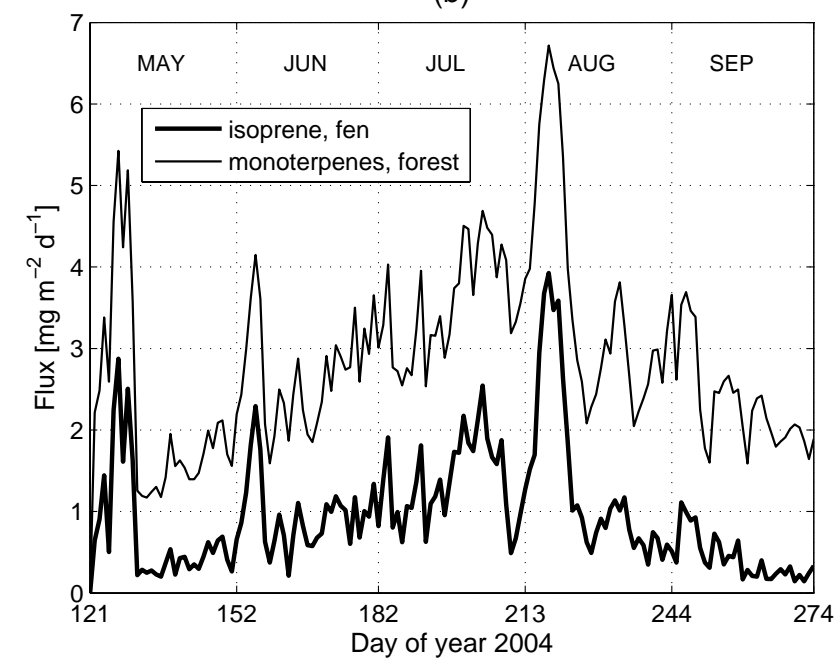

Fig. 6. Panel (a) shows daily minimum and maximum temperatures as well as daily maximum of photosynthetic photon flux density (PPFD) measured at Hyytiälä station in May-September 2004. Panel (b) shows isoprene flux from the fen (thick line) and monoterpene flux from the forest (thin line) calculated using the meteorological data and Guenther emission algorithms. According to the model, the total isoprene emission was $150 \mathrm{mg} \mathrm{m}^{-2}$ and the total monoterpene emission was $440 \mathrm{mg} \mathrm{m}^{-2}$ during the period.

May, separately, are lower than the mean emission potential but due to the small datasets it is impossible to say whether this is explained just by low $C_{L} C_{T}$ values at these times.

To evaluate the amount of isoprene emitted by the $\mathrm{Si}$ ikaneva fen during one growing season, we used the Guenther algorithm with the isoprene emission potential obtained in this study. Meteorological data (Fig. 6a) including air temperature and photosynthetic photon flux density was obtained from nearby Hyytiälä station. There were some untypical features in the weather patterns during summer 2004. In the beginning of May there was an exceptionally warm period, the end of July was cold and very rainy and the beginning of August was quite warm. The algorithm was run for the period May to September 2004 (Fig. 6b).

For comparison, we calculated also the monoterpene emission from Scots pine forests using solely temperature dependent emission model (Guenther et al., 1993) with the emission potential obtained by Rinne et al. (2000a). The calculated daily isoprene fluxes were highest, almost $4 \mathrm{mg} \mathrm{m}^{-2} \mathrm{~d}^{-1}$, during a warm spell in August, but most of the time they were considerably lower. Total isoprene flux from Siikaneva fen was about $150 \mathrm{mg} \mathrm{m}^{-2}$ whereas the monoterpene emission from forests was $440 \mathrm{mg} \mathrm{m}^{-2}$. However, the molar emissions are comparable.

In Finland, about $10 \%$ of the total land surface area was covered by fens before the intensive drainage programs of $20^{\text {th }}$ century (Minkkinen et al., 2002). The land use change from wetlands to coniferous forests has probably changed the VOC emission pattern during the 20th century. Today most of the undrained peatlands are in Northern Finland where wetlands are likely to be significant source of isoprene to the atmosphere.

\section{Conclusions}

In the present study, emissions of various light hydrocarbons from a boreal fen were measured using the REA technique. Significant fluxes of methane and isoprene were measured during the growing season. The measured isoprene emissions were observed to follow the isoprene emission algorithm (Guenther, 1997) with standard emission potential of $680 \mu \mathrm{g} \mathrm{m}^{-2} \mathrm{~h}^{-1}$. Total isoprene emission during the growing season from the fen was $34 \%$ of the total monoterpene emission from the nearby Scots pine forest. In some regions, like northern boreal zone, isoprene emissions from fens are likely to be significant for the total terpenoid emissions.

Mean methane emission over the whole measurement period was $4.3 \mathrm{mg} \mathrm{m}^{-2} \mathrm{~h}^{-1}$, which is in the same range than the fluxes measured by chamber and EC techniques. Large temporal variations occurred in the methane flux. Fluxes of the other light hydrocarbons and halogenated compounds were below detection limits.

Acknowledgements. We thank J. Meronen for building measurement infrastructure on Siikaneva fen. This project is funded by the Academy of Finland (project 206162).

Edited by: T. Laurila 


\section{References}

Ammann, C. and Meixner, F. X.: Stability dependence of the relaxed eddy accumulation coefficient for various scalar quantities, J. Geophys. Res., 107, 4071, doi:10.1029/2001JD000649, 2002.

Archibold, O. W.: Ecology of World Vegetation, Chapman \& Hall, London, 510 pp., ISBN 0-412-44290-6, 1995.

Bubier, J., Moore, T., Savage, K., and Crill, P.: A comparison of methane flux in a boreal landscape between a dry and a wet year, Global Biogeochem. Cycle, 19, GB1023, doi:10.1029/2004GB002351, 2005.

Businger, J. A. and Oncley, S. P.: Flux Measurement with Conditional Sampling, J. Atmos. Ocean. Technol., 7, 349-352, 1990.

Calogirou, A., Larsen, B. R., Brussol, C., Duane, M., and Kotzias, D.: Decomposition of Terpenes by Ozone during Sampling on Tenax, Anal. Chem., 68, 1499-1506, 1996.

Chameides, W. L., Fehsenfeld, F., Rodgers, M. O., Cardelino, C., Martinez, J., Parrish, D., Lonneman, W., Lawson, D. R., Rasmussen, R. A., Zimmerman, P., Greenberg, J., Middleton, P., and Wang, T.: Ozone Precursor Relationships in the Ambient Atmosphere, J. Geophys. Res., 97, 6037-6055, 1992.

Christensen, C. S., Hummelshøj, P., Jensen, N. O., Lasren, B., Lohse, C., Pilegaard, K., and Skov, H.: Determination of the terpene flux from orange species and Norway spruce by relaxed eddy accumulation, Atmos. Environ., 34, 3057-3067, 2000.

Claeys, M., Grahan, B., Vas, G., Wang, W., Vermeylen, R., Pashynska, V., Cafmeyer, J., Guyon, P., Andreae, M. O., Artaxo, P., and Maenhaut, W.: Formation of Secondary Organic Aerosols Through photooxidation of Isoprene, Science, 303, 1173-1176, 2004.

Dimmer, C. H., Simmonds, P. G., Nickless, G., and Bassford, M. R.: Biogenic fluxes of halomethanes from Irish peatland ecosystems, Atmos. Environ., 35, 321-330, 2001.

Drebs, A., Nordlund, A., Karlsson, P., Helminen, J., and Rissanen, P.: Climatological statistics of Finland 1971-2000, Finnish Meteorological Institute, Helsinki, 99 pp., ISBN 951-697-568-2, 2002.

Enhalt, D., Prather, M., Dentener, F., Derwent, R., Dlugokencky, E., Holland, E., Isaksen, I., Katima, J., Kirchhoff, V., Matson, P., Midgley, P., and Wang, M.: Atmospheric Chemistry and Greenhouse Gases, in: Climate Change 2001: The Scientific Basis 2001, edited by: Houghton, J. T., Ding, Y., Griggs, D. J., et al., Cambridge University Press, Cambridge, 881 pp., ISBN 052180767-0, 2001.

Gaman, A., Rannik, Ü., Aalto, P., Pohja, T., Siivola, E., Kulmala, M., and Vesala, T.: Relaxed Eddy Accumulation System for Size-Resolved Aerosol Particle Flux Measurements, J. Atmos. Oceanic Technol., 6, 933-943, 2004.

Gore, A. P. J. (Ed.): Ecosystems of the World 4b Mires: Swamp, bog, fen and moor - Regional studies, Elsevier, Amsterdam, 440 pp., ISBN 044-44-2003-7, 1983.

Guenther, A. B., Zimmerman, P. R., Harley, P. C., Monson, R. K., and Fall, R.: Isoprene and Monoterpene Emission Rate Variability: Model Evaluations and Sensitivity Analyses, J. Geophys. Res., 98, 12 609-12 617, 1993.

Guenther, A., Hewitt, C. N., Erickson, D., Fall, R., Geron, C., Graedel, T., Harley, P., Klinger, L., Lardau, M., McKay, W. A., Pierce, T., Scholes, B., Steinbrecher, R., Tallamraju, R., Taylor, J., and Zimmerman, P.: A global model of natural volatile organic compound emissions, J. Geophys. Res., 100, 8873-8892,
1995.

Guenther, A., Baugh, W., Davis, K., Hampton, G., Harley, P., Klinger, L., Vierling, L., Zimmerman, P., Allwine, E., Dilts, S., Lamb, B., Westberg, H., Baldocchi, D., Geron, C., and Pierce, T.: Isoprene fluxes measured by enclosure, relaxed eddy accumulation, surface layer gradient, mixed layer gradient, and mixed layer mass balance techniques, J. Geophys. Res., 101, 18555 $18567,1996$.

Guenther, A.: Seasonal and spatial variations in natural volatile organic compound emissions, Ecol. Appl., 7, 34-45, 1997.

Hakola, H., Rinne, J., and Laurila, T.: The hydrocarbon emission rates of tea-leafed willow (Salix phylicifolia), silver birch (Betuna pendula) and european aspen (Populus tremula), Atmos. Environ., 32, 1825-1833, 1998.

Hakola, H., Laurila, T., Rinne, J., and Puhto, K.: The ambient concentrations of biogenic hydrocarbons at a northern European, boreal site, Atmos. Environ., 34, 4971-4982, 2000.

Hakola, H., Laurila, T., Lindfors, V., Hellén, H., Gaman, A., and Rinne, J.: Variation of the VOC emission rates of birch species during the growing season, Boreal Env. Res., 6, 237-249, 2001.

Hakola, H., Tarvainen, V., Laurila, T., Hiltunen, V., Hellén, H., and Keronen, P.: Seasonal variation of VOC concentrations above a boreal coniferous forest, Atmos. Environ., 37, 1623-1634, 2003.

Hoffmann, T., Odum, J. R., Bowman, F., Collins, D., Klockow, D., Flagan, R. C., and Seinfeln, J. H.: Formation of organic aerosols from the oxidation of biogenic hydrocarbons, J. Atmos. Chem., 26, 189-222, 1997.

Isidorov, V. A., Zenkevich, I. G., and Ioffe, B. V.: Volatile organic compounds in the atmosphere of forests, Atmos. Environ., 19, $1-8,1985$.

Janson, R.: Monoterpene emission of Scots pine and Norwegian spruce, J. Geophys. Res., 98, 2839-2850, 1993.

Janson, R. W. and De Serves, C.: Isoprene emissions from boreal wetlands in Scandinavia, J. Geophys. Res., 103, 25 513-25 517, 1998.

Janson, R., De Serves, C., and Romero, R.: Emission of isoprene and carbonyl compounds from a boreal forest and wetland in Sweden, Agric. For. Meteorol., 98-99, 671-681, 1999.

Janson, R. W. and De Serves, C.: Acetone and monoterpene emissions from the boreal forest in northern Europe, Atmos. Environ., 35, 4629-4637, 2001.

Klinger, L. F., Zimmermann, P. R., Greenberg, J. P., Heidt, L. E., and Guenther, A. B.: Carbon trace gas fluxes along a successional gradient in the Hudson Bay lowland, J. Geophys. Res., 99, 1469-1494, 1994.

Kulmala, M., Hämeri, K., Mäkelä, J. M., Aalto, P. P., Pirjola, L., Väkevä, M., Nilsson, E. D., Koponen, I. K., Buzorius, G., Keronen, P., Rannik, Ü., Laakso, L., Vesala, T., Bigg, K., Seidl, W., Forkel, R., Hoffmann, T., Spanke, J., Janson, R., Shimmo, M., Hansson, H.-C., O’Dowd, C., Becker, E., Paatero, J., Teinilä, K., Hillamo, R., Viisanen, Y., Laaksonen, A., Swietlicki, E., Salm, J., Hari, P., Altimir, N., and Weber, R.: Biogenic aerosol formation in the boreal forest, Boreal Environ. Res., 5, 281-297, 2000.

Laurila, T. and Hakola, H.: Seasonal cycle of $\mathrm{C}_{2}-\mathrm{C}_{5}$ hydrocarbons over the Baltic Sea and Northern Finland, Atmos. Environ., 30, 1597-1607, 1996.

Laurila, T., Tuovinen, J.-P., Lohila, A., Hatakka, J., Aurela, M., Thum, T., Pihlatie, M., Rinne, J., and Vesala, T.: Measuring methane emissions from a landfill using a cost-effective mi- 
crometeorological method, Geophys. Res. Lett., 32, L19808, doi:10.1029/2005GL023462, 2005.

Lee, A., Schade, G. W., Holzinger, R., and Goldstein, A. H.: A comparison of new measurements of total monoterpene flux with improved measurements of speciated monoterpene flux, Atmos. Chem. Phys., 5, 505-513, 2005.

Lindfors, V., Laurila, T., Hakola, H., Steinbrecher, R., and Rinne, J.: Modeling speciated terpenoid emissions from the European boreal forest, Atmos. Environ., 34, 4983-4996, 2000.

Olofsson, M., Ek-Olausson, B., Jensen, N. O., Langer, S., and Ljungström, E.: The flux of isoprene from a willow plantation and the effect on local air quality, Atmos. Environ., 39, 20612070, 2005.

Pattey, E., Desjardins, R. L., Westberg, H., Lamb, B., and Zhu, T.: Measurement of isoprene emissions over a Black spruce stand using a tower-based relaxed eddy-accumulation system, J. Appl. Meteorol., 38, 870-877, 1999.

Riis, T. and Sand-Jensen, K.: Growth reconstruction and photosynthesis of aquatic mosses: influence of light, temperature and carbon dioxide at depth, J. Ecol., 85, 359-372, 1997.

Rinnan, R., Rinnan, Å., Holopainen, T., Holopainen, J. K., and Pasanen, P.: Emission of non-methane volatile organic compounds (VOCs) from boreal peatland microcosms - effects of ozone exposure, Atmos. Environ., 39, 921-930, 2005.

Rinne, J., Hakola, H., and Laurila, T.: Vertical fluxes of monoterpenes above a Scots pine stand in a boreal vegetation zone, Phys. Chem. Earth (B), 24, 711-715, 1999.

Rinne, J., Hakola, H., Laurila, T., and Rannik, Ü.: Canopy scale monoterpene emissions of Pinus sylvestris dominated forests, Atmos. Environ., 34, 1099-1107, 2000a.

Rinne, J., Tuovinen, J.-P., Laurila, T., Hakola, H., Aurela, M., and Hypén, H.: Measurements of hydrocarbon fluxes by a gradient method above a northern boreal forest, Agric. For. Meteorol., 102, 25-37, 2000b.

Rinne, J., Riutta, T., Pihlatie, M., Aurela, M., Haapanala, S., Tuovinen, J.-P., Tuittila, E.-S., Laurila, T., Laine, J., and Vesala, T.: Measurements of methane emissions from a boreal wetland, Proc. 1st iLEAPS Science Conference, in: Report Series in Aerosol Science, 79, 293-294, ISBN 952-5027-66-X, 2006.
Saarnio, S., Alm, J., Silvola, J., Lohila, A., Nykänen, H., and Martikainen, P. J.: Seasonal variation in $\mathrm{CH} 4$ emissions and production and oxidation potentials at microsites on an oligotrophic pine fen, Oecologia, 110, 414-422, 1997.

Simpson, D., Winiwarter, W., Börjesson, G., Cinderby, S., Ferreiro, A., Guenther, A., Hewitt, C. N., Janson, R., Khalil, M. A. K., Owen, S., Pierce, T. E., Puxbaum, H., Shearer, M., Skiba, U., Steinbrecher, R., Tarrason, L., and Öquist, M. G.: Inventorying emissions from nature in Europe, J. Geophys. Res., 104, 81138152, 1999.

Spanke, J., Rannik, Ü., Forkel, R., Nigge, W., and Hoffmann, T.: Emission fluxes and atmospheric degradation of monoterpenes above a boreal forest: field measurements and modelling, Tellus B, 53, 406-422, 2001.

Strack, M., Waddington, J. M., and Tuittila, E.-S.: Effect of water table drawdown on northern peatland methane dynamics: Implications for climate change, Global Biogeochem. Cycles, 18, GB4003, doi:10.1029/2003GB002209, 2004.

Suyker, A. E., Verma, S. B., Clement, R. J., and Billesbach, D. P. Methane flux in a boreal fen: Season-long measurement by eddy correlation, J. Geophys. Res., 101, 28 637-28 647, 1996.

Varner, R. K., Crill, P. M., and Talbot, R. W.: Wetlands, a potentially significant source of atmospheric methyl bromide and methyl chloride, Geophys. Res. Lett., 26, 2433-2436, 1999.

Vasander, H. (Ed.): Peatlands in Finland. Finnish Peatland Society, Helsinki, 168 pp., ISBN 952-90-7971-0, 1996.

Vesala, T., Haataja, J., Aalto, P., Altimir, N., Buzorius, G., Garam, E., Hämeri, K., Ilvesniemie, H., Jokinen, V., Keronen, P., Lahti, T., Markkanen, T., Mäkelä, J. M., Nikinmaa, E., Palmroth, S., Palva, L., Pohja, T., Pumpanen, J., Rannik, Ü., Siivola, E., Y1italo, H., Hari, P., and Kulmala, M.: Long-term field measurements of atmosphere-surface interactions in boreal forest combineng forest ecology, micrometeorology, aerosol physics and atmospheric chemistry, Trends in Heat, Mass and Momentum Transfer, 4, 17-35, 1998.

Zielinska, B., Sagebiel, J. C., Harshfield, G., Gertler, A. W., and Pierson, W. R.: Volatile organic compounds up to $\mathrm{C}_{20}$ emitted from motor vehicles; measurement methods, Atmos. Environ., 30, 2269-2286, 1996. 